


\section{STUDIES IN INTERNATIONAL POLITICAL ECONOMY}

\section{Stephen D. Krasner, Editor}

Ernst B. Haas, Consulting Editor

1. Scientists and World Order: The Uses of Technical Knowledge in Intemational Organizations

Ernst B. Haas, Mary Pat Williams, and Don Babai

2. Pollution, Politics, and Intemational Law: Tankers at Sea

R. Michael M'Gonigle and Mark W. Zacher

3. Plutonium, Power, and Politics: International Arrangements for the Disposition of Spent Nuclear Fuel

Gene I. Rochlin

4. National Power and the Structure of Foreign Trade

Albert $\mathrm{O}$. Hirschman

5. Congress and the Politics of U.S. Foreign Economic Policy, 1929-1976

Robert A. Pastor

6. Natural Resources and the State: The Political Economy of Resource Management

Oran R. Young

7. Resource Regimes: Natural Resources and Social Institutions

Oran R. Young

8. Managing Political Risk Assessment: Strategic Response to Environmental Change Stephen J. Kobrin

9. Between Dependency and Autonomy: India's Experience with the International Computer Industry

Joseph M. Grieco

10. The Problems of Plenty: Energy Policy and International Politics

Peter F. Cowhey

11. Standing Guard: Protecting Foreign Capital in the Nineteenth and Twentieth

Centuries

Charles Lipson

12. Structural Conflict: The Third World Against Global Liberalism

Stephen D. Krasner 
13. Liberal Protectionism: The International Politics of Organized Textile Trade Vinod K. Aggarwal

14. The Politicized Market Economy: Alcohol in Brazil's Energy Strategy

Michael Barzelay

15. From Marshall Plan to Debt Crisis: Foreign Aid and Development Choices in the World Economy

Robert Wood

16. The Power of Ideology: The Quest for Technological Autonomy in Argentina and Brazil

Emanuel Adler

17. Ruling the Waves: The Political Economy of International Shipping Alan Cafruny

18. Banker to the Third World: U.S. Pontfolio Investment in Latin America, $1900-1986$

Barbara Stallings

19. Unequal Alliance: The World Bank, The Intcriational Monetary Fund, and the Philippines

Robin Broad

20. Managing the Frosen South: The Creation and Evolution of the Antartic Treaty System

M.J. Peterson 

Managing the Frozen South 



\section{MANAGING THE FROZEN SOUTH}

The Creation and Evolution of the Antarctic Treaty System

\section{J. PETERSON}

UNIVERSITY OF CALIFORNIA PRESS

Berkeley $\cdot$ Los Angeles · London 
University of California Press

Berkeley and Los Angeles, California

University of California Press, Ltd.

London, England

C) 1988 by

The Regents of the University of California

Library of Congress Cataloging-in-Publication Data

Peterson, M. J., 1949-

Managing the frozen south.

(Studies in international political economy)

Bibliography: $p$.

Includes index.

1. Antarctic regions-International status.

2. Mining law-Antarctic regions. I. Title. II. Series.

JX4084.A5P48 1988 341.2'9'09989 87-5078

ISBN 0-520-05997-2 (alk. paper)

Printed in the United States of America

123456789 
For B. Jean and Carl A. Peterson 
